\title{
Free serum cortisol: quantification applying equilibrium dialysis or ultrafiltration and an automated immunoassay system
}

\author{
Michael Vogeser ${ }^{1, *}$, Patrick Möhnle ${ }^{2}$ and Josef \\ Briegel $^{2}$ \\ ${ }^{1}$ Institute of Clinical Chemistry, Hospital of the \\ University of Munich, Munich, Germany \\ ${ }^{2}$ Department of Anesthesiology, Hospital of the \\ University of Munich, Munich, Germany
}

\begin{abstract}
Background: Quantification of bioactive, free serum cortisol concentrations can characterize adrenocortical function more appropriately compared to total serum cortisol measurement. Ultrafiltration or equilibrium dialysis of serum samples allow direct measurement of free serum cortisol concentrations but respective methods have poorly been validated so far. The aim of our study was to investigate the analytical performance of free serum cortisol measurement employing equilibrium dialysis and ultrafiltration.

Methods: Two commercially available ultrafiltration devices and self-assembled dialysis cells, respectively, were studied. Cortisol was quantified in filtrate or dialysate using an automated immunoassay system. Using two serum pools, the inter-assay coefficient of variation was determined for the three methods and a method comparison was performed.

Results: Inter-assay coefficients of variation $(n=10)$ between $3.2 \%$ and $14.8 \%$ were observed in the imprecision study. Method comparison demonstrated close agreement between free serum cortisol results obtained by ultrafiltration and equilibrium dialysis, respectively (equilibrium dialysis $=1.2 \times$ ultrafiltration + $3.9 \mathrm{nmol} / \mathrm{L} ; \mathrm{r}=0.99 ; \mathrm{n}=35$ ).

Conclusions: Direct quantification of free serum cortisol after equilibrium dialysis or ultrafiltration of the samples offers acceptable reproducibility and results in close agreement can be obtained. Both methods can potentially be introduced into a routine laboratory setting.

Clin Chem Lab Med 2007;45:521-5.
\end{abstract}

Keywords: corticosteroid-binding globulin (CBG); equilibrium dialysis; free serum cortisol; ultrafiltration.

*Corresponding author: Michael Vogeser, MD, Institute of Clinical Chemistry, Hospital of the University of Munich, Marchioninistraße 15, 81377 Munich, Germany Phone: + 49897095 3221, Fax: + 498970953240 , E-mail: Michael.Vogeser@med.uni-muenchen.de

\section{Introduction}

Measurement of total serum concentrations of thyroid and steroid hormones is of limited biological validity, because the bioavailability of these hormones is substantially determined by variable concentrations and binding characteristics of the respective hormone binding proteins. This problem has been addressed for thyroid function testing by the introduction of direct measuring free hormone assays applicable to unprocessed serum samples. In the diagnostic workup of patients with suspected Cushing's or Addison's disease in an outpatient setting, quantification of salivary cortisol may avoid the bias of total serum cortisol measurement caused by variable concentrations of the corticosteroid-binding globulin (CBG) (1). Besides typical endocrine diseases, reliable analytical methods are needed to disclose adrenocortical dysfunction in critical illness (2-5), a condition which is typically associated with substantial and variable depletion of CBG and albumin (3,5-10). Determination of salivary cortisol concentrations may be confounded due to reduced flow of saliva in critically ill patients (11); consequently, there is substantial interest in accurate methods to determine the serum concentration of free cortisol concentrations in critical care medicine. Indeed superior diagnostic performance of free serum cortisol determination in critically ill patients has been suggested in previous reports $(5$, 12, 13).

Based on the binding characteristics of CBG, a calculation of free serum cortisol concentrations can be performed from the concentrations of total serum cortisol, CBG, and albumin, respectively $(12,14)$. This approach has been used in a number of investigations, but important limitations have to be recognized: besides the immunoreactive concentration of CBG, individual variations in the tertiary structure of CBG can determine cortisol binding $(15,16)$. Furthermore, no automated test for CBG measurement is available, and calculated free serum cortisol incorporates the inaccuracy of two immunometric assays. As a potentially more accurate approach, direct quantification of free serum cortisol after equilibrium dialysis of serum samples may be applied $(5,17,18)$. As applies for equilibrium dialysis, a protein-free fraction can also be obtained from serum samples by ultrafiltration techniques $(14,19)$.

So far, few data have been reported on the analytical reproducibility of free serum cortisol measurement using equilibrium dialysis or ultrafiltration, and on the agreement between these analytical approaches. Therefore, the aim of the present work was to per- 
form a comparative validation of these techniques, with quantification of cortisol in dialysate or filtrate using a modern fully automated immunoanalyzer system.

\section{Materials and methods}

Equilibrium dialysis of serum samples was essentially performed as described previously $(17,18,20)$. For conditioning of dialysis membranes, an approx. 20-cm long piece of a dry membrane tube (Carl Roth $\mathrm{GmbH}$, Karlsruhe, Germany, regenerated cellulose, molecular weight cut off 4000-6000, $25 \mu \mathrm{m}$ wall thickness) was placed into $1.5 \mathrm{~L}$ of deionized water heated to $50^{\circ} \mathrm{C}$; after $30 \mathrm{~min}$ of gentle stirring, the water was exchanged by fresh deionized water of room temperature; again after a further $30 \mathrm{~min}$ the water was exchanged. In this water, the membrane can be kept for several weeks at $+4^{\circ} \mathrm{C}$. Dialysis cells were assembled from $1.5 \mathrm{~mL}$ polypropylene reaction vials. The lid of a vial was cut and filled with Roche Cobas Elecsys Universal Diluent (approx. $250 \mu \mathrm{L}$ ) (Roche Diagnostics, Mannheim, Germany), here serving as the dialysis buffer. A piece of the preconditioned dialysis membrane was laid upon the filled lid and the body of the vial was placed upside-down onto the covered lid, thereby fixing the membrane. The bottom of the vial was cut away and $1 \mathrm{~mL}$ of serum was filled into the cell which was subsequently closed with a laboratory film. These dialysis cells were kept at $37^{\circ} \mathrm{C}$ overnight (16-18 h). After disassembling of the cells, the dialysate was harvested out of the lid with a pipette tip.

A specially designed dialysis cell device is commercially available and offers easier handling compared to the described self-assembled dialysis cells (Micro-Equilibrium Dialyzer ${ }^{\mathrm{TM}}$; Harvard Apparatus, Holliston, MA, USA; www.harvardapparatus.com). In this cell, however, a volume ratio between sample and dialysis buffer of 1:1 is fixed, in contrast to a ratio of $4: 1$ with the self-assembled cells. It can be reasonably assumed that, the higher the sample-to-dialysate volume ratio is, the less the actual binding conditions between cortisol and proteins are disturbed in dialysis cells compared to the physiological condition in blood. Furthermore, we found poor reproducibility of the Micro-Equilibrium Dialyzer ${ }^{\mathrm{TM}}$ for free serum cortisol measurement in initial trials, and therefore decided not to further study this commercial dialysis cell.

Two different ultrafiltration devices were investigated in our study: Centrisart I (Sartorius AG, Goettingen, Germany, cut-off 10,000; www.sartorius.com); and Centrifree YM-30 (cut-off 30,000, Millipore Corporation, Billerica, USA; www.millipore.com). These devices are centrifuged to achieve filtration of the loaded serum samples through a membrane by centrifugal force. In order to remove preservatives from the filtration membranes before use, the devices were loaded with $1 \mathrm{~mL}$ of deionized water, which was discarded after centrifugation. Subsequently, $1 \mathrm{~mL}$ of serum was filled into the filtration devices which were then kept at $37^{\circ} \mathrm{C}$ for $30 \mathrm{~min}$ to achieve equilibrium of protein binding. The ultrafiltration devices were then centrifuged at $2100 \mathrm{~g}$ for $7 \mathrm{~min}$ (Centrisart) or $25 \mathrm{~min}$ (Centrefree) at a temperature setting of $37^{\circ} \mathrm{C}$. A thermostated Hettich Rotanta RP (Hettich, Tuttlingen, Germany) benchtop centrifuge was used. The temperature within the centrifuge chamber was recorded by an electronic device; typically, variation between $35-40^{\circ} \mathrm{C}$ was observed during a centrifugation run. Significant between-sample variation of ultrafiltrate volumes obtained from $1 \mathrm{~mL}$ of sample was observed in initial trials for both devices tested; the duration of the centri-

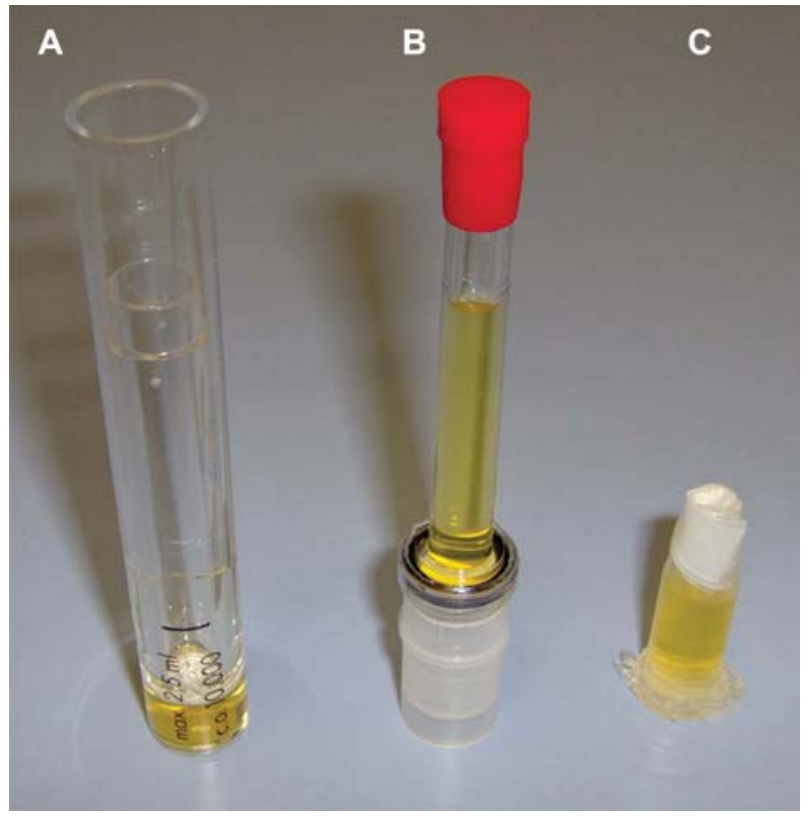

Figure 1 Sartorius ultrafiltration device, Millipore ultrafiltration device, and equilibrium dialysis cell, each loaded with $1 \mathrm{~mL}$ of serum.

fugation was optimized for either system in order to obtain at least $200 \mu \mathrm{L}$ of ultrafiltrate in the majority of samples processed, however, ultrafiltrate volumes between $200 \mu \mathrm{L}$ and $400 \mu \mathrm{L}$ were typically observed.

Ultrafiltration devices and a dialysis cell are shown in Figure 1.

Ultrafiltrate and dialysate samples, respectively, were all assayed for cortisol concentrations using the Roche Cobas Cortisol assay implemented on a Roche Elecsys $2010 \mathrm{immu}$ noanalyzer system (Roche Diagnostics, Mannheim, Germany).

To study the imprecision of the methods, two serum pools were prepared from residual clinical samples; pool \#1 was prepared from serum of intensive care patients; pool \#2 from serum of outpatients. Aliquots of these pools were stored at $-20^{\circ} \mathrm{C}$ and were analyzed in each ten independent analytical runs over a 6 -week period. Total serum cortisol $^{11}$ was $723 \mathrm{nmol} / \mathrm{L}$ in pool 1 and $439 \mathrm{nmol} / \mathrm{L}$ in pool 2; CBG was $36.9 \mu \mathrm{g} / \mathrm{mL}$ in pool 1 and $68.1 \mu \mathrm{g} / \mathrm{mL}$ in pool 2; albumin was $21 \mathrm{~g} / \mathrm{L}$ in pool 1 and $43 \mathrm{~g} / \mathrm{L}$ in pool 2 .

Since the Centrifree devices offered superior reproducibility compared to the Centrisart devices (see Results section), only the Centrifree devices were used for a subsequent method comparison study. For this study, 30 residual serum samples were used (9 outpatients; 21 intensive care unit patients not receiving exogenous steroids), and an additional five pool samples. Total serum cortisol concentrations were determined using the Roche Cobas cortisol assay and the concentrations of the CBG were determined with a radioimmunoassay (Asbach Medical Products, Obrigheim, Germany); C-reactive protein (CRP) was quantified with a latex-enhanced immuno-turbidimetric assay, albumin with the bromocresol green photometric color test.

A calculation of individual free serum cortisol concentration from total cortisol and CBG concentrations was performed as described by Coolens et al. (14), corrected for serum albumin concentrations according to Ho et al. (12).

1) Conversion of units: Cortisol: $[\mathrm{nmol} / \mathrm{L}] \times 0.0362 \rightarrow[\mu \mathrm{g} / \mathrm{dL}]$ $[\mu \mathrm{g} / \mathrm{dL}] \times 27.6 \rightarrow[\mathrm{nmol} / \mathrm{L}]$ 
Total serum cortisol concentrations and free serum cortisol results obtained from the three analytical approaches were compared according to Passing and Bablok (21) with calculation of Pearson's $r$.

\section{Results and discussion}

Best reproducibility was observed for the Centrifree ultrafiltration device with inter-assay coefficients of variation clearly below $10 \%$ for both pools (Table 1 ). The reproducibility of the equilibrium dialysis method was found inferior but still acceptable with an interassay coefficient of variation of approx. $15 \%$ for pool \#2.

In a previous article, Lentjes et al. (19) have reported an important impact of temperature variations within the centrifuge on free serum cortisol results by ultrafiltration, requiring specially manufactured and not commercially available laboratory equipment. We observed, in contrast, acceptable reproducibility also using a standard centrifuge with relatively poor temperature control. Conversely, in our experience, washing of the filtration devices with distilled water (as described above) is essential for reproducible results.

Concentrations of total cortisol, CBG, albumin and the $\mathrm{CRP}$, respectively, were as follows in 35 samples used for method comparison:

Total serum cortisol [nmol/L]: mean 558 (SD 367); median 461; interquartile range (IQR) 337-762; range 71.8-1634. CBG $[\mu \mathrm{g} / \mathrm{mL}]$ : mean 39.6 (SD 17.7); median 34.9; IOR 23.9-50.3; range 16.1-80.7. Albumin [g/L]: mean 32 (SD 12); median 26; IQR 22-44; range 14-50; CRP [mg/L]: mean 86 (SD 87); median 37; IQR $6.0-154$; range $<5.0-266$.

Poor nominal correlation was found between total serum cortisol concentrations and free serum cortisol results; this applied for calculated free cortisol $(r=0.87)$, for measured free cortisol after ultrafiltration $(r=0.75)$, and measured free cortisol after equilibrium dialysis $(r=0.76)$ (Figure $2 \mathrm{~A}-\mathrm{C}$ ). These plots highlight the non-linear binding characteristics between cortisol and CBG as predicted by the results from Coolens et al. (14).

Excellent correlation was observed between free serum cortisol results obtained by equilibrium dialysis (ED) and ultrafiltration (UF), respectively (Figure 3); however, slightly higher results were found with the dialysis method:

$E D=1.2 \times U F+3.9 \mathrm{nmol} / \mathrm{L}$

(95\% Cl for slope, 1.10-1.20; 95\% Cl for intercept, $2.8-5.5 \mathrm{nmol} / \mathrm{L} ; \mathrm{r}=0.99$ ).

The close agreement between free serum cortisol measured after equilibrium dialysis and ultrafiltration, respectively, found in our investigation is in accordance with the data reported by Ho et al. (12).

Substantially higher free serum cortisol concentrations were found by the directly measuring methods compared to calculated free serum cortisol (CALC) for the entire set of 35 samples studied:

$E D=2.0 \times C A L C-10.8 \mathrm{nmol} / \mathrm{L}$

(95\% Cl for slope, 1.56-2.41; 95\% Cl for intercept, $-30.4-1.1 \mathrm{nmol} / \mathrm{L} ; \mathrm{r}=0.96$ ) (Figure $4 \mathrm{~A}$ )

$\mathrm{UF}=1.7 \times \mathrm{CALC}-11.9 \mathrm{nmol} / \mathrm{L}$

(95\% $\mathrm{Cl}$ for slope, $1.30-2.21 ; 95 \% \mathrm{Cl}$ for intercept, $-33.1--2.5 \mathrm{nmol} / \mathrm{L} ; \mathrm{r}=0.96$ ) (Figure $4 \mathrm{~B}$ ).

ED [nmol/L]: mean 160 (SD 273); median 80.0; IQR 16.6-149; range 3.0-1333

UF [nmol/L]: mean 135 (SD 237); median 63.5; IQR 16.6-119; range 2.8-1148

CALC [nmol/L]: mean 77.3 (SD 102); median 38.6; IQR 19.3-77.3; range 3.6-433

Interestingly, in the subset of samples with CRP concentrations below $5.0 \mathrm{mg} / \mathrm{L}(\mathrm{n}=9$; albumin concentrations ranging from 39 to $46 \mathrm{~g} / \mathrm{L}$ ) closer agreement was found between calculated and measured free serum cortisol concentrations compared to the entire set of samples studied [for CRP $<5.0 \mathrm{mg} / \mathrm{L}$, mean free serum cortisol results: ED $16.6 \mathrm{nmol} / \mathrm{L}$ (SD 8.3); UF $11.0 \mathrm{nmol} / \mathrm{L}$ (SD 6.1); CALC, $19.3 \mathrm{nmol} / \mathrm{L}$ (SD 11.0)].

The mean percentage of free cortisol from total cortisol was $3.7 \%$ and $6.0 \%$ in samples with CRP concentrations below $5.0 \mathrm{mg} / \mathrm{L}$, as determined with ultrafiltration and equilibrium dialysis, respectively; a

Table 1 Inter-assay imprecision $(n=10)$ of three methods for the quantification of free serum cortisol concentrations.

\begin{tabular}{|c|c|c|c|c|c|c|}
\hline & \multicolumn{3}{|l|}{ Pool \#1 } & \multicolumn{3}{|l|}{ Pool \#2 } \\
\hline & $\begin{array}{l}\text { Equilibrium } \\
\text { dialysis }\end{array}$ & $\begin{array}{l}\text { Ultrafiltration, } \\
\text { Sartorius } \\
\text { device }\end{array}$ & $\begin{array}{l}\text { Ultrafiltration, } \\
\text { Millipore } \\
\text { device }\end{array}$ & $\begin{array}{l}\text { Equilibrium } \\
\text { dialysis }\end{array}$ & $\begin{array}{l}\text { Ultrafiltration, } \\
\text { Sartorius } \\
\text { device }\end{array}$ & $\begin{array}{l}\text { Ultrafiltration, } \\
\text { Millipore } \\
\text { device }\end{array}$ \\
\hline $\begin{array}{l}\text { Mean free cortisol } \\
\text { concentration }\end{array}$ & $183 \mathrm{nmol} / \mathrm{L}$ & $124 \mathrm{nmol} / \mathrm{L}$ & $181 \mathrm{nmol} / \mathrm{L}$ & $17.7 \mathrm{nmol} / \mathrm{L}$ & $11.9 \mathrm{nmol} / \mathrm{L}$ & $17.4 \mathrm{nmol} / \mathrm{L}$ \\
\hline$\%$ Free cortisol & $25.3 \%$ & $17.1 \%$ & $25.0 \%$ & $4.0 \%$ & $2.7 \%$ & $4.0 \%$ \\
\hline $\begin{array}{l}\text { Coefficient of } \\
\text { variation }\end{array}$ & $7.3 \%$ & $8.3 \%$ & $3.2 \%$ & $14.8 \%$ & $10.0 \%$ & $6.9 \%$ \\
\hline
\end{tabular}



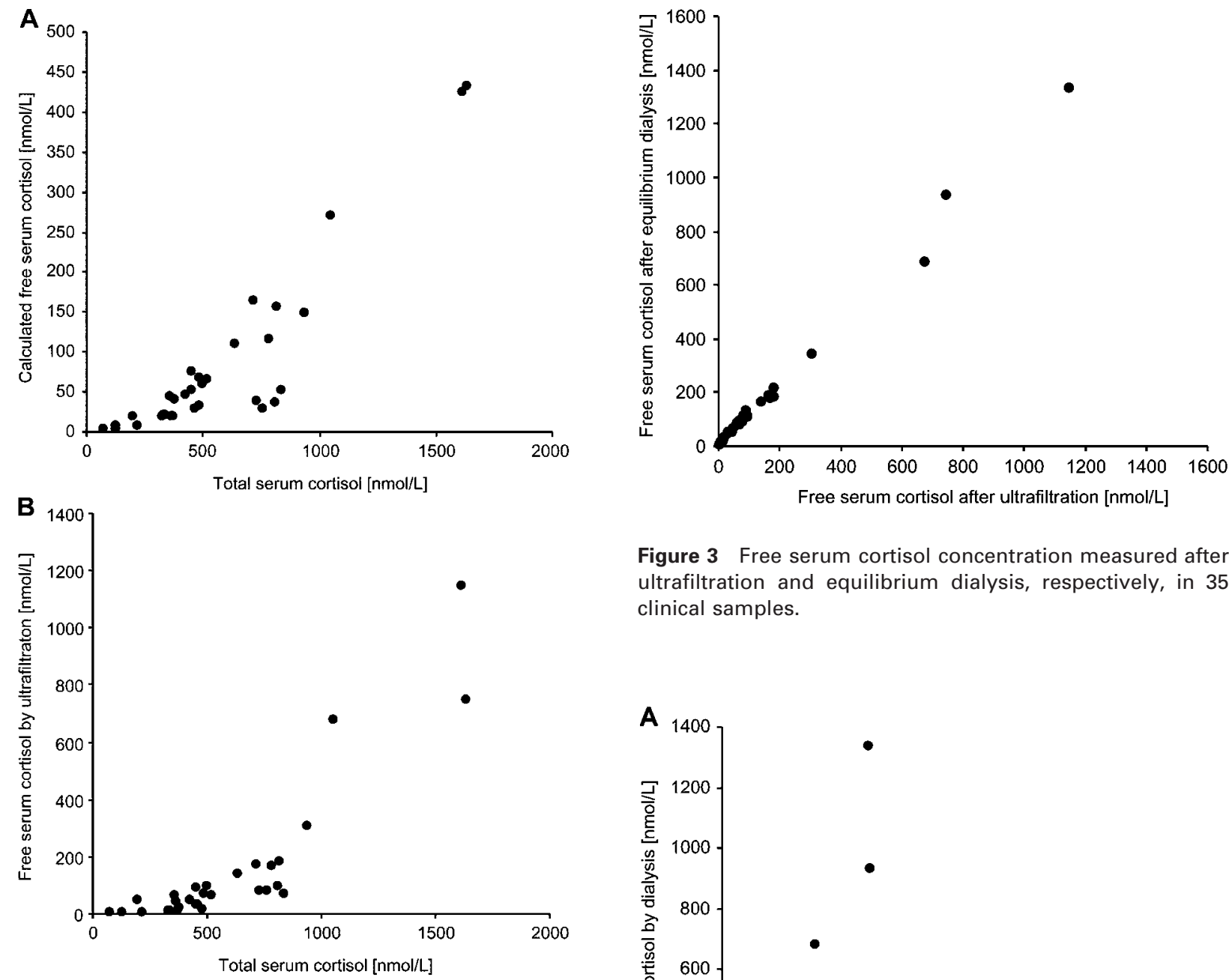

Figure 3 Free serum cortisol concentration measured after ultrafiltration and equilibrium dialysis, respectively, in 35 clinical samples.
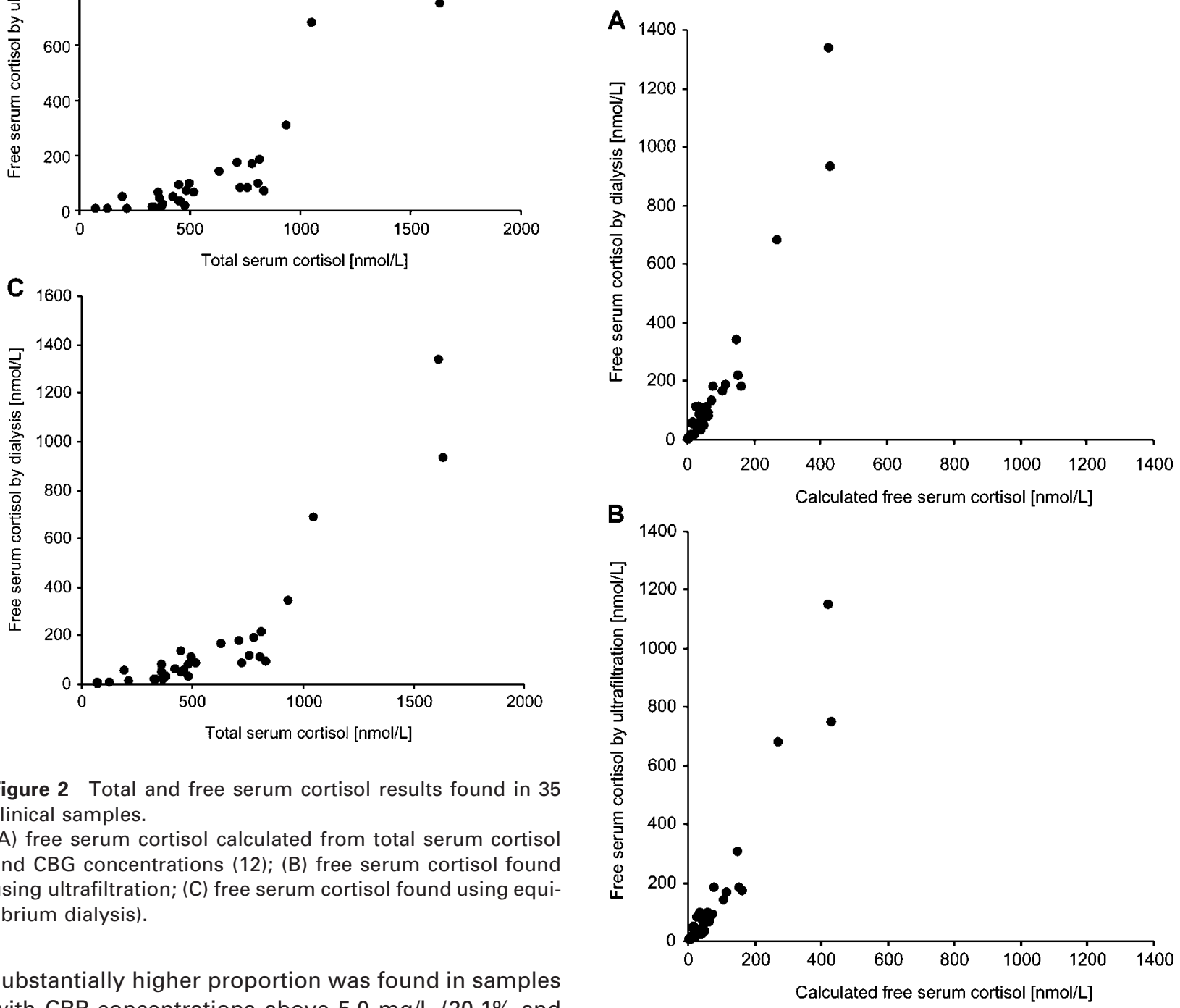

Figure 2 Total and free serum cortisol results found in 35 clinical samples.

(A) free serum cortisol calculated from total serum cortisol and CBG concentrations (12); (B) free serum cortisol found using ultrafiltration; (C) free serum cortisol found using equilibrium dialysis).

substantially higher proportion was found in samples with CRP concentrations above $5.0 \mathrm{mg} / \mathrm{L}(20.1 \%$ and $23.8 \%$, for ultrafiltration and equilibrium dialysis, respectively).

Obviously, calculation of free serum cortisol from the concentrations of total cortisol, CBG, and albumin,

Figure 4 Free serum cortisol concentrations found in 35 clinical samples by calculation from total serum cortisol and CBG concentrations, equilibrium dialysis $(A)$ and ultrafiltration (B), respectively. 
respectively, according to Coolens et al. (14) and Ho et al. (12), seems to underestimate actual free serum cortisol concentrations, particularly in patients in a pronounced acute phase response. In respective samples from critically ill patients, not only the concentrations but also the binding characteristics of CBG can be assumed to be substantially altered compared to normal conditions $(7,15)$. Therefore, direct measurement of free serum cortisol applying ultrafiltration or equilibrium dialysis seems to be more accurate in characterizing individual adrenocortical function in critical illness.

According to our validation data, both equilibrium dialysis- and ultrafiltration-based direct measurement of free serum cortisol can be recommended for further research on adrenocortical function in critical illness. Since free serum cortisol results can be obtained within a few hours using ultrafiltration and automated cortisol measurement, this approach is potentially applicable also in a routine laboratory setting. However, issues of technical standardization as well as internal and external quality control for measuring free serum cortisol first have to be addressed very carefully.

\section{References}

1. Findling JW, Raff H. Screening and diagnosis of Cushing's syndrome. Endocrinol Metab Clin North Am 2005;34: 385-402.

2. Annane D, Sebille V, Troche G, Raphael JC, Gajdos P, Bellissant $E$. A 3-level prognostic classification in septic shock based on cortisol levels and cortisol response to corticotropin. J Am Med Assoc 2000;283:1038-45.

3. Cooper MS, Stewart PM. Corticosteroid insufficiency in acutely ill patients. N Engl J Med 2003;348:727-34.

4. Annane D, Bellissant E, Bollaert PE, Briegel J, Keh D, Kupfer Y. Corticosteroids for severe sepsis and septic shock: a systematic review and meta-analysis. Br Med J 2004; 329:480.

5. Hamrahian AH, Oseni TS, Arafah BM. Measurements of serum free cortisol in critically ill patients. N Engl J Med 2004;350:1629-38.

6. Savu L, Zouaghi H, Carli A, Nunez EA. Serum depletion of corticosteroid binding activities, an early marker of human septic shock. Biochem Biophys Res Commun 1981;102:411-9.

7. Pugeat $M$, Bonneton A, Perrot D, Rocle-Nicolas B, Lejeune $H$, Grenot $C$, et al. Decreased immunoreactivity and binding activity of corticosteroid-binding globulin in serum in septic shock. Clin Chem 1989;35:1675-9.
8. Bernier J, Jobin N, Emptoz-Bonneton A. Decreased corticosteroid-binding globulin in burn patients: relationship with interleukin-6, and fat in nutritional support. Crit Care 1998;26:452-60.

9. Vogeser M, Felbinger TW, Kilger E, Roll W, Fraunberger $\mathrm{P}$, Jacob K. Corticosteroid-binding globulin and free cortisol in the early postoperative period after cardiac surgery. Clin Biochem 1999;32:213-6

10. Beisenhuizen A, Thijs LG, Vermes I. Patterns of corticosteroid-binding globulin and the free cortisol index during septic shock and multitrauma. Intensive Care Med 2001;27:1584-91.

11. Dennesen $P$, van der Ven $A$, Vlasveld M, Lokker L, Ramsay $G$, Kessels $A$, et al. Inadequate salivary flow and poor oral mucosal status in intubated intensive care unit patients. Crit Care Med 2003;31:781-6.

12. Ho JT, Al-Musalhi H, Chapman MJ, Quach T, Thomas PD, Bagley CJ, et al. Septic shock and sepsis: a comparison of total and free plasma cortisol levels. J Clin Endocrinol Metab 2006;91:105-14.

13. Arafah BM. Hypothalamic pituitary adrenal function during critical illness: limitations of current assessment methods. J Clin Endocrinol Metab 2006;91:3725-45.

14. Coolens JL, Van Baelen H, Heyns W. Clinical use of unbound plasma cortisol as calculated from total cortisol and corticosteroid-binding globulin. J Steroid Biochem 1987;26:197-202.

15. Pemberton PA, Stein PE, Pepys MB, Potter JM, Carrell RW. Hormone binding globulins undergo serpin conformational change in inflammation. Nature 1988;336: 257-8.

16. Rosner W. Plasma steroid-binding globulins. Endocrinol Metab Clin North Am 1991;20:697-720.

17. Vogeser M, Briegel J, Zachoval R. Dialyzable free cortisol after stimulation with Synacthen. Clin Biochem 2002;35: 539-43.

18. Vogeser M, Groetzner J, Küpper C, Briegel J. Free serum cortisol during the postoperative acute phase response determined by equilibrium dialysis liquid chromatography-tandem mass spectrometry. Clin Chem Lab Med 2003:41:146-51.

19. Lentjes EG, Romijn F, Maassen RJ, de Graaf L, Gautier $\mathrm{P}$, Moolenaar AJ. Free cortisol in serum assayed by temperature-controlled ultrafiltration before fluorescence polarization immunoassay. Clin Chem 1993;39:251821.

20. Reinard T, Jacobsen HJ. An inexpensive small volume equilibrium dialysis system for protein-ligand binding assays. Anal Biochem 1989;176:157-60.

21. Passing $H$, Bablok W. A new biometrical procedure for testing the equality of measurements from two different analytical methods. J Clin Chem Clin Biochem 1983;21: 709-20.

Received December 8, 2006, accepted January 4, 2007 